\title{
Increase in number and size of kidney concretions as a result of PCP exposure in the freshwater snail Planorbarius corneus (Gastropoda, Pulmonata)
}

\author{
Göran I. V. Klobučar*, Jasna Lajtner, Radovan Erben
}

Department of Zoology, Faculty of Science, University of Zagreb, Rooseveltov $\operatorname{trg} 6$, 10000 Zagreb, Croatia

\begin{abstract}
Molluscan kidneys are able to excrete solids in the urine in the form of concretions. It is thought that increased formation of these concretions occur under pollutant, environmentally or reproductive induced stress. This study examined the formation of concretions in the kidney of the freshwater snail Planorbarius corneus L. experimentally exposed to pentachlorophenol (PCP). Light microscopic histopathological analysis of the PCP-exposed P. corneus revealed significantly enhanced production of the kidney concretions when compared to the kidneys of control individuals. Measurements of the number of kidney concretions, the apparent area of the concretions, and the epithelial area filled with concretions indicated an increase in the number and size of concretions in all treated snails. Lipofuscin content of excretory cell concretions was detected.
\end{abstract}

KEY WORDS: Kidney concretions $\cdot$ Mollusca $\cdot$ Planorbarius corneus $\cdot$ Pentachlorophenol

Resale or republication not permitted without written consent of the publisher

\section{INTRODUCTION}

The role of the excretory system of molluscs in bioaccumulation and depuration has as yet been insufficiently investigated. Molluscan kidney consists of a tubule enclosing a luminal cavity derived from the coelom. The nephrocytes lining the luminal surface of the tubule are involved in the secretion of waste and the resorption of metabolites from the urinary fluid (Simkiss \& Mason 1983). One of the peculiarities of molluscan kidneys is their ability to produce and excrete solids in the urine in the form of concretions (Potts 1968, Doyle et al. 1978, Andrews 1981, Angulo \& Moya 1989, Marigómez et al. 1995). It is thought that increased formation of these concretions occurs under pollutant (Yevich 1980, Seiler \& Morse 1988), environmentally (Krahelska 1910) or reproductive (Doyle et al. 1978) induced stress. Studies by Doyle et al. (1978) and others (Yevich 1980, Sunila 1987, Regoli et al. 1992) point out that the kidney concretions may possibly serve as biological monitors of pollution.

*E-mail: gklobuca@public.srce.hr
Molluscs are widely used in different biomonitoring projects. Their histopathological analysis provides information about the general health of the animals and contaminant-specific changes in the tissues. Although laboratory as well as field studies suggest that pollutants cause toxic effects to molluscs, the histopathological effects of chemical contaminants have not generally been measured (Sunila 1986, 1989, Hemelraad 1990, Marigómez 1990a). When measured, different qualitative, semi-quantitative, and quantitative approaches were used (Lowe 1988, Cajaraville 1990). Only recently has computer-assisted image analysis begun to be used in ecotoxicological research to provide information regarding cellular and tissue abnormalities (Etxeberria et al. 1994, Krishnakumar et al. 1994, Soto \& Marigómez 1997). The use of computerassisted image analysis improves the precision and objectivity of the measurements while being much less time-consuming.

Pentachlorophenol (PCP) has been chosen as a reference compound because its chemistry, toxicology and fate in the environment are fairly well understood (Rand \& Petrocelli 1985, WHO 1987). 
The purpose of this investigation was to determinate whether appearance of concretions in the kidney of the freshwater snail Planorbarius corneus exposed to PCP is dose dependent.

\section{MATERIALS AND METHODS}

Adult specimens of the freshwater pulmonate snail Planorbarius corneus L. were collected from the Odra River $\left(16^{\circ} 08^{\prime} \mathrm{E}, 45^{\circ} 41^{\prime} \mathrm{W}\right)$, Croatia. Acclimatization of snails to laboratory conditions in dechlorinated tap water lasted for $48 \mathrm{~h}$. The specimens used for the study averaged $22 \pm 3 \mathrm{~mm}$ in height. PCP (sodium salt) was obtained from BDH Chemicals Ltd, Poole, United Kingdom. Stock solutions of PCP (100 mg PCP $\left.{ }^{-1}\right)$ were prepared in distilled water. The experiment was carried out in aerated glass dishes, each containing $5 \mathrm{l}$ of dechlorinated tap water. Based on the results of the preliminary mortality tests (the $\mathrm{LC}_{50}$ value for $96 \mathrm{~h}$ was $1420 \mu \mathrm{g} \mathrm{PCP} \mathrm{l}^{-1}$ ), 3 concentrations were chosen: 450, 600 and $800 \mu \mathrm{g} \mathrm{PCP} \mathrm{l}^{-1}$. The experiment was repeated 3 times, with parallel controls. One dish was used as the control, receiving dechlorinated tap water only. There were 20 snails per dish. The test solutions and control water were renewed daily. The experiment lasted for $7 \mathrm{~d}$. The temperature and $\mathrm{pH}$ of the test solutions and control water were determined every $24 \mathrm{~h}$ by routine procedures (APHA 1985). The physicochemical characteristics of the test water were as follows: temperature 20 to $21^{\circ} \mathrm{C}$; $\mathrm{pH} 7.6$ to 8.0 ; dissolved oxygen 7.0 to 8.2 ; hardness $288 \mathrm{mg} \mathrm{CaCO}_{3} \mathrm{l}^{-1}$. The snails were not fed throughout the assay because we wanted to prevent any possible changes in concretion production due to the digestion and excretion of food.

For histological analyses, live specimens were removed from each exposure concentration and control on Days 2, 4 and 7. Nine to ten individuals were analyzed per experimental group. Snails were placed in Bouin's fixative for $24 \mathrm{~h}$. After fixation, the snails were embedded in paraffin and cut with a microtome into 6 to $8 \mu \mathrm{m}$ thick slices. The sections were then stained with haematoxylin and eosin for histopathological analysis. Lipofuscin content of excretory cell concretions was detected by using the Schmorl reaction (Pearse 1968). From each snail, 2 sections that contained kidney tissue were examined. Five images of kidney saccular portion were randomly taken from each section. The image size was approximately $0.1224 \mathrm{~mm}^{2}$. Tissue sections were analyzed using computer assisted image analysis. The image analysis system consists of a color CCD video camera (Sony $151 \mathrm{P}$ ) mounted on a light microscope and a PC where the images were examined utilizing SFORM image analysis system (made by VAMS d.o.o., Zagreb, Croatia). We measured the average number of concretions $\left(N_{\mathrm{ca}}=N_{\mathrm{c}} / A_{\mathrm{e}}\right)$, the average apparent area of concretion $\left(A_{\mathrm{ca}}=A_{\mathrm{c}} / N_{\mathrm{c}}\right)$, and the average epithelial area filled with concretions $\left(A_{\mathrm{ec}}=A_{\mathrm{e}} / A_{\mathrm{c}} \times 100\right)$, where $N_{\mathrm{C}}=$ number of concretions in the epithelium, $A_{\mathrm{e}}=$ area of epithelium, and $A_{\mathrm{C}}=$ area of the concretions found in the epithelium. Statistical analyses were measured by using non parametric Kruskal-Wallis and Mann-Whitney $U$-tests.

\section{RESULTS}

The kidney of Planorbarius corneus consists of a small saccular portion, an elongated tubular portion, and a short ureter that opens into the mantle cavity at the pneumostome. The internal surface of the nephridium is much increased by the formation of multiple folds. The epithelial cells of the wall of the saccular portion are columnar and are taller than those of the tubular portion but are arranged in the same manner. The folds are clothed with the excretory epithelium of nephrocytes (Fig. 1a). The apical portion of nephrocytes consists of a vacuole in which the excretory product accumulates, often in the form of large sphere concretions (Fig. 1b). The nuclei are round to oval and are basal in position. The folds consist of connective tissue containing blood vessels and sinuses (Fig. 1a). Another feature characterizing the transition of the saccular portion into the tubular portion is the absence of excretion concretions from the tubular portion epithelium. The crystalline concretions are lightly refractive, round bodies with a central core (Fig. 1b) and appear yellowish-brown in haematoxylin-eosin preparations. Generally, only 1 concretion is formed per cell. Eventually, the cells extrude the concretions into the lumen of the kidney from where they are excreted (Fig. 1b).

\section{Histopathological measurements}

On Day 2 of exposure only the highest concentration increased the number of concretions in the kidney epithelium. After $4 \mathrm{~d}$ of exposure, massive production of concretions was observed in nephrocytes of snails treated with 600 and $800 \mathrm{\mu g} \mathrm{l}^{-1}$ PCP (Fig. 2a). Lower concentration (450 $\mathrm{\mu g}^{-1}$ ) of PCP exerted significantly enhanced concretion formation on Day 7 of the exposure (Fig. 1c), which then matched the slightly depressed numbers of the 2 highest concentrations (Fig. 1d).

The average apparent area of the concretion found in the kidneys of the control group during the whole experiment ranged from 23 to $43 \mu^{2}$ (5.4 to $7.4 \mu \mathrm{m}$ in diameter). On Day 4 of the experiment, a significant enlargement of concretions was observed in all treated 


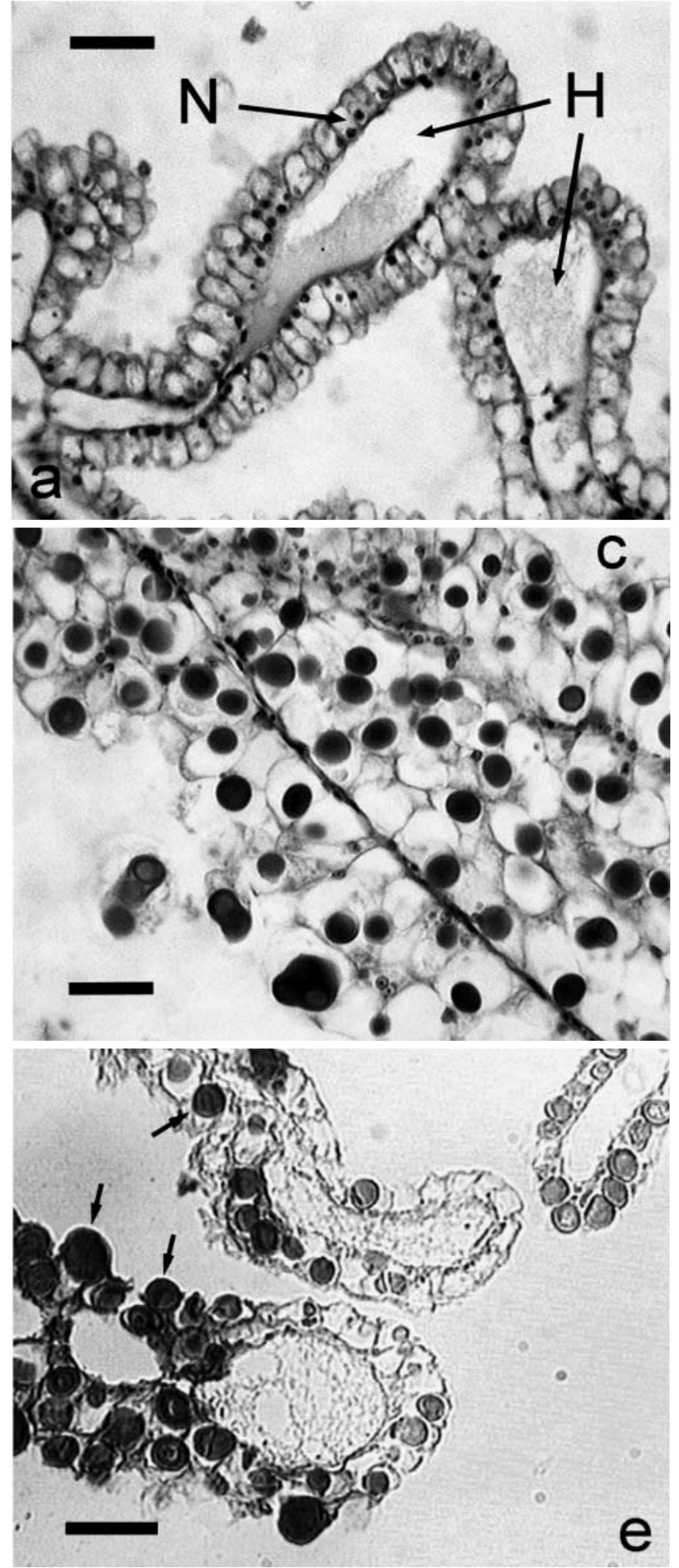

groups of snails with the highest response $\left(252 \mu \mathrm{m}^{2}\right.$, diameter: $19.7 \mu \mathrm{m}$ ) in $600 \mu \mathrm{g} \mathrm{PCP}{ }^{-1}$ (Fig. 2b). Surprisingly, on Day 7 of the experiment, the same concentration showed much lower values.

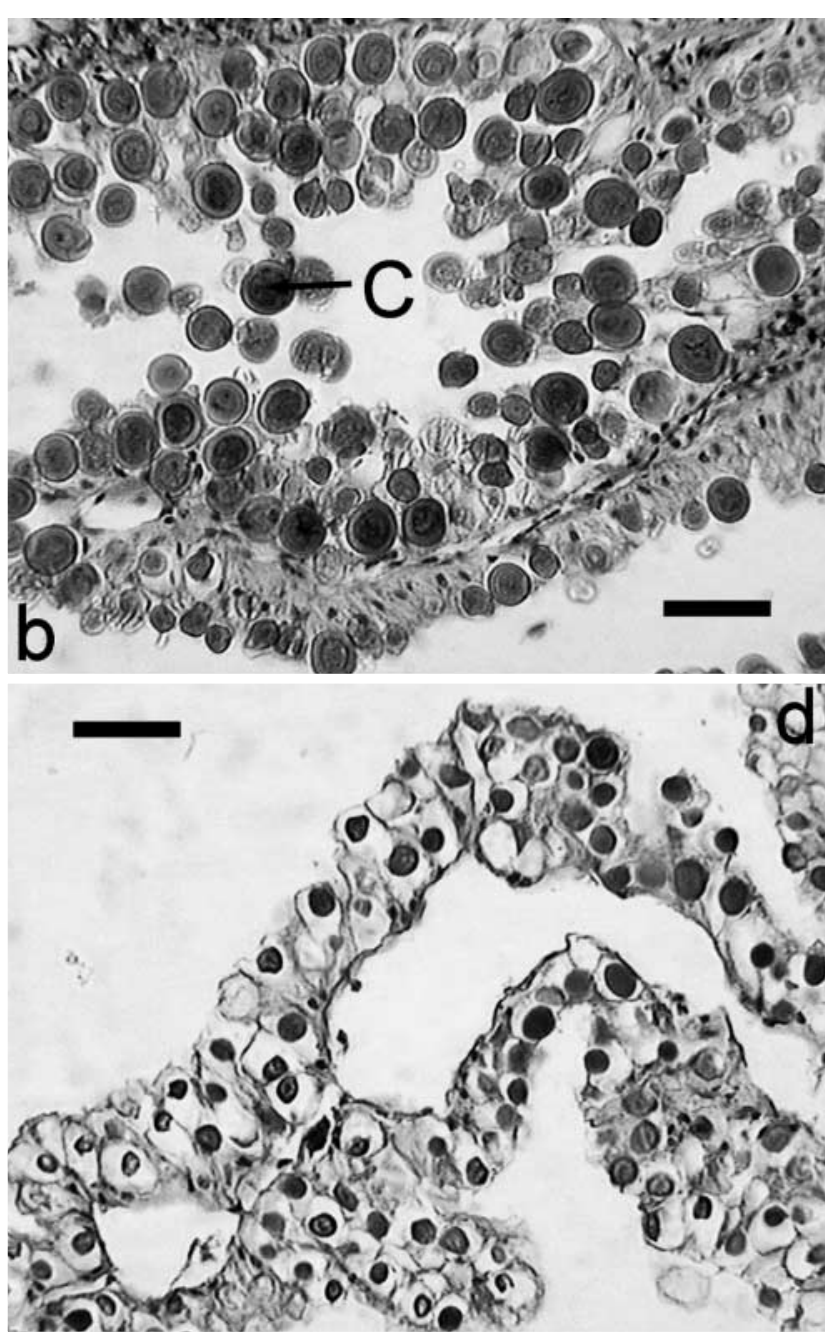

Fig. 1. Excretory organ of a Planorbarius corneus. Scale bar = $50 \mu \mathrm{m}$. (a) Excretory organ of an untreated snail on Day 4 of the experiment. The folds are clothed with the excretory epithelium of nephrocytes (N). Hemolymphatic spaces $(\mathrm{H})$. (b) Snail treated with $600 \mu \mathrm{g} \mathrm{l} \mathrm{l}^{-1}$ pentachlorophenol (PCP) for $4 \mathrm{~d}$. Massive production of concretions (C). (c) Snail treated with $450 \mathrm{\mu g} \mathrm{l}^{-1} \mathrm{PCP}$ for $7 \mathrm{~d}$. Increased number of concretions. (d) Snail treated with $800 \mu \mathrm{g} \mathrm{l}^{-1} \mathrm{PCP}$ for $7 \mathrm{~d}$. (e) Intensive staining of concretions with Schmorl reaction (arrows) in excretory organ of a snail treated with $450 \mu \mathrm{g} \mathrm{l}^{-1} \mathrm{PCP}$ for $7 \mathrm{~d}$

When analyzed for the average epithelial area filled with concretions, on Day 2 of exposure, only the kidney epithelium of the snails treated with the highest concentration $\left(800 \mu \mathrm{g} \mathrm{PCP} \mathrm{l}^{-1}\right)$ showed a small but 

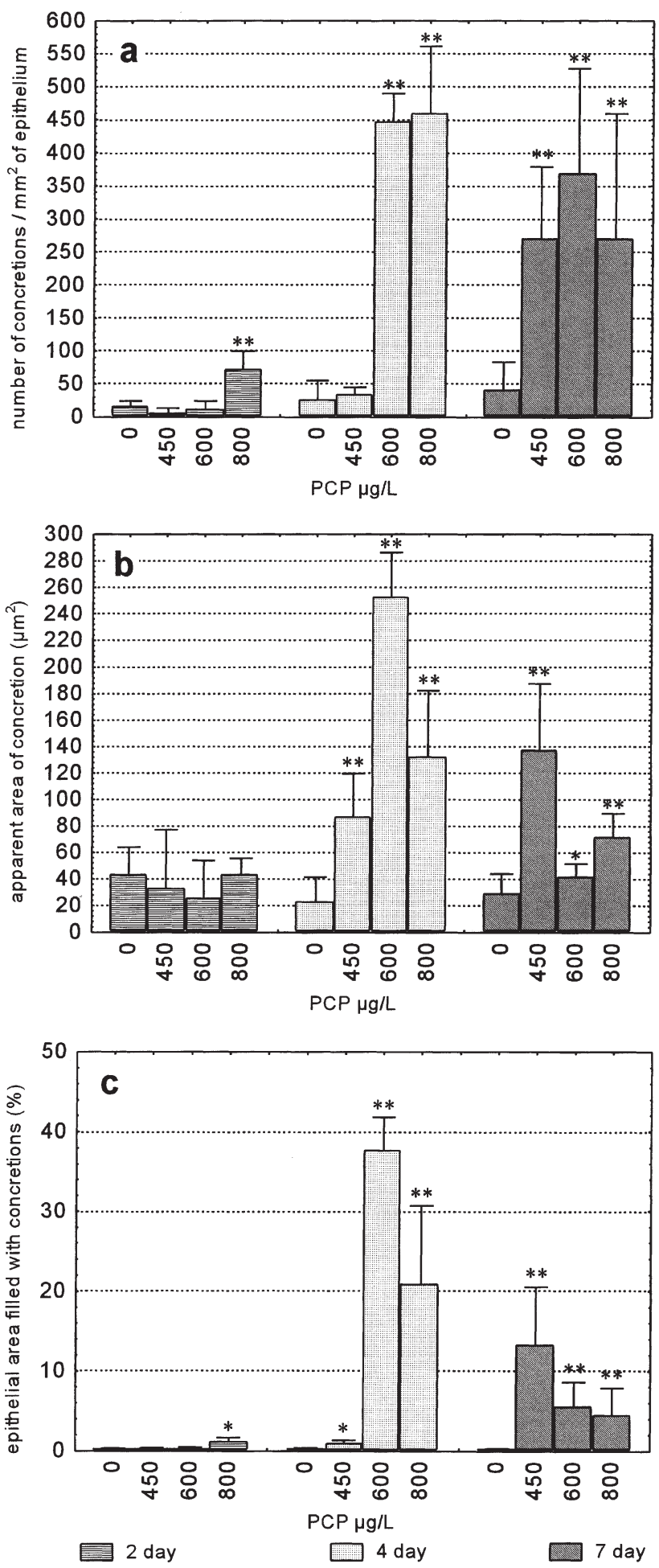

Fig. 2. Changes in the average size and number of concretions in the kidneys of the freshwater snail Planorbarius corneus exposed to 450,600 and $800 \mu \mathrm{g} \mathrm{l}^{-1} \mathrm{PCP}$ for 2, 4 and 7 d. Statistically significant values from respective control indicated by ${ }^{*} p \leq 0.05$ and ${ }^{* *} p \leq 0.01$. (a) Average number $\left( \pm \mathrm{SD}\right.$ ) of kidney concretions per $\mathrm{mm}^{2}$ of epithelium. (b) Average apparent area $( \pm \mathrm{SD})$ of the single concretion. (c) Average epithelial area $( \pm \mathrm{SD})$ filled with concretions significant increase compared to the control animals (Fig. 2c). On all the other observed days, the percentage was significantly larger in the treated snails than in the non-treated ones. On Day 4 of the experiment, the highest percentage $(37.6 \%)$ was detected in $600 \mu \mathrm{g}$ $\mathrm{PCP}^{-1}$. In these snails, the concretions occupied almost the entire interior of the nephrocytes, and consequent disruption of nephrocytes became apparent (Fig. 1b). It is evident from Fig. 2c that this value was followed with $21 \%$ epithelia, filled with concretions observed in snails treated with $800 \mu \mathrm{gCPl}^{-1}$ (Fig. 1d). The reaction of snails treated with the lowest concentration of PCP $\left(450 \mathrm{\mu g} \mathrm{l}^{-1}\right)$ was slower and the highest percentage $(13.11 \%)$ of concretion abundance was apparent on Day 7 of the experiment (Fig. 1C).

In our experiment, all of the yellowish-brown concretions (both control and treated snails) in nephrocytes of Planorbarius corneus were demonstrated to be Schmorl positive (Fig. 1e).

\section{DISCUSSION}

Light microscopical analysis of the PCP-exposed Planorbarius corneus revealed a multiple increase in the number and size of kidney concretions when compared to the kidneys of control snails. An increase is evident in all measurements used ( $\left.N_{\mathrm{ca},} A_{\mathrm{ca},} A_{\mathrm{ec}}\right)$. Up to now, this kind of event has been mostly associated with heavy metal exposure (Sunila 1986, 1989, BallanDufrancais et al. 1990, Hemelraad et al. 1990, Hyne et al. 1992, Giamberini et al. 1996) although one can find work concerning toxic effects of non metals on molluscan kidney (Cajaraville et al. 1990).

A mutual characteristic of all analyses used ( $N_{\text {ca }}, A_{\text {ca }}$ $\left.A_{\mathrm{ec}}\right)$ is that the 2 highest concentrations elicited a quicker and stronger response than the lowest one. Also, snails exposed to the lowest concentration $\left(450 \mu \mathrm{gCP}^{-1}\right.$ ) exhibited greater concretion growth whilst in those exposed to higher concentrations the effect appeared to be an increase in the number of concretions. The decrease in number and size of concretions in snails treated with 600 and $800 \mu \mathrm{gCP}^{-1}$ after Day 4 of exposure could be caused by the higher turnover rate in these concentrations.

Increase in the number of concretions has been observed in the kidneys of bivalves Mercenaria mercenaria and Mytilus edulis under heavy metal stress (Rheinberger et al. 1979, Sunila 1986) and in the kidneys of bivalve Donacilla cornea exposed to $\mathrm{Cu}$ and $\mathrm{Cd}$ (Regoli et al. 1992). Light microscopical observations of Marigómez et al. (1990a) on the excretory epithelium of Littorina littorea revealed that the amount of concretions increases at low Cd exposures. The kidneys of the same species showed increased occurrence of mem- 
brane-bound dark bodies which became enlarged after $96 \mathrm{~h}$ of exposure to naphthalene (Cajaraville et al. 1990).

Seiler \& Morse (1988) reported that the kidney cells of Mya arenaria specimens collected from polluted sediments showed qualitatively higher numbers of granules when compared to those from a nonpolluted site. A comprehensive observation on this matter was made by Doyle et al. (1978), who noted that, sometimes, concretions are also detected in molluscs from apparently nonpolluted areas. Thus, pollution may be primarily related to concretion formation in that it serves as a stress to the organism. In molluscs collected from unpolluted environments, stress factors which may lead to concretion formation are abnormal temperature or salinity or proximity in the reproductive cycle to spawning. Indeed, a significant increase in the number of the concretions was observed in land pulmonates rendered inactive by cold or drying (Krahelska 1910). Cyclic changes in the reproductive system and digestive diverticula, as well as reactions to parasites and microorganisms, must be taken into account before an attempt is made to correlate histopathological changes with pollution (Sunila 1987). In between spawning, during the sexual repose, the nephrocytes are usually free of concretions (Yevich 1980). Planorbarius corneus does not spawn in autumn (Costil \& Daguzan 1995), at the time when our experiments were performed. We found no egg capsules during our experiment; however, influences from reproductive activity could not be completely excluded.

The average apparent area of the single concretion in non-treated Planorbarius corneus ranged between 23 and $43.1 \mu^{2}$ (5.4 to $7.4 \mu \mathrm{m}$ in diameter respectively), which is similar to the size of concretions ( 3 to $7 \mu \mathrm{m}$ in diameter) observed in Arion ater (Angulo \& Moya 1989) and excretion granules measuring 5 to $20 \mu \mathrm{m}$ in nephrocytes of Lymnaea stagnalis (Wendelaar Bonga \& Boer 1969). The maximum observed concretion diameter for $P$. corneus in our experiment was $19.7 \mu \mathrm{m}\left(600 \mu \mathrm{g} \mathrm{PCP} \mathrm{l}^{-1}\right)$. Yevich (1980) also observed that quahogs (Mercenaria mercenaria, Arctica islandica, Mercenaria campehensis) collected from polluted areas had more and larger-sized concretions in the kidneys than those found in molluscs collected from a non-polluted site.

The granules in the different invertebrate tissue can be classified into 3 types depending on cytochemical characteristics: iron rich granules, Cu-S containing granules and $\mathrm{Mg} / \mathrm{Ca}$ concretions (Viarengo \& Nott 1993). In gastropods, the mineralized $\mathrm{Mg} / \mathrm{Ca}$ concretions exist as phosphate and carbonate types. In the nephrocytes of gastropods, as well as bivalves, concretions are essentially calcium phosphates (Doyle et al. 1978, Taylor \& Andrews 1991, Regoli et al. 1992, Marigómez et al. 1995, Giamberini et al. 1996). In addi- tion to calcium phosphate, lipofuscin and other lipid pigments (chromolipids, ceroid pigments) have been shown to accumulate in degenerative digestive and excretory cells in terrestrial (Angulo \& Moya 1989, Vivar et al. 1990) and aquatic (Wendelaar Bonga \& Boer 1969) pulmonate gastropods and to be present in the tertiary lysosomes of marine molluscs (Cajaraville et al. 1990, Marigómez et al. 1990b). In the Archaeogastropoda, lipofuscin is one of the most important constituents of the excretory granules (Andrews 1985). The presence of lipofuscin in the concretions of Planorbarius corneus has been confirmed in our research. Lipofuscins are mainly lipid peroxidation end products which are accumulated in the lysosomes as insoluble lipoprotein granules. PCP induced increased lipid peroxidation in the digestive gland of $P$. corneus exposed to 450 and $800 \mathrm{\mu g} \mathrm{l}^{-1}$ of PCP (Klobučar et al. 1997). Increased oxygen consumption that has been noted as an initial response of PCP-exposed aquatic animals (Weinbach 1954, Holmberg et al. 1972) could have caused increased lipid peroxidation (Roszell \& Anderson 1996). We can assume that higher production of kidney concretions in PCP-exposed snails could also be partly due to PCP-induced increase in lipid peroxidation.

Our studies revealed that snails exposed to PCP had more and larger-sized concretions then non-treated individuals but no dose-dependent pattern was observed. Increased concretion formation in kidneys of Planorbarius corneus is a useful stress indicator, but its role as a possible biological monitor of pollution requires more research.

Acknowledgements. This work was supported by the Scientific Research Council of the Republic of Croatia within the framework of Project No. 119105.

\section{LITERATURE CITED}

Andrews EB (1981) Osmoregulation and excretion in prosobranch gastropods. Part 2. Structure in relation to function. J Molluscan Stud 47:248-289

Andrews EB (1985) Structure and function in the excretory system of archaeogastropods and their significance in the evolution of gastropods. Phil Trans R Soc Lond B 310: 383-406

Angulo E, Moya J (1989) Electron microscopical studies on the renal concretions of the slug, Arion ater (Linnaeus, 1758) (Mollusca, Pulmonata). Zool Anz 222:273-280

APHA (1985) Standard methods for the examination of water and wastewater, 16th edn. American Public Health Association, New York

Ballan-Dufrancais C, Jeantet AY, Coulon J (1990) Cytological features of mussels (Mytilus edulis) in situ exposed to an effluent of the titanium dioxide industry. Ann Inst Océanogr 66:1-18

Cajaraville MP, Marigómez JA, Angulo E (1990) Ultrastructural study of the short-term toxic effects of naphthalene on the kidney of the marine prosobranch Littorina littorea. J Invertebr Pathol 55:215-224 
Costil K, Daguzan J (1995) Comparative life cycle and growth of two freshwater gastropod species, Planorbarius corneus (L.) and Planorbis planorbis (L.). Malacologia 37:53-68

Doyle LJ, Blake NJ, Woo CC, Yevich P (1978) Recent biogenic phosphorite: concretions in mollusk kidneys. Science 199: 1431-1433

Etxeberria M, Sastre I, Cajaraville MP, Marigómez JA (1994) Digestive lysosome enlargement induced by experimental exposure to metals $(\mathrm{Cu}, \mathrm{Cd}$, and $\mathrm{Zn})$ in mussels collected from a zinc-polluted site. Arch Environ Contam Toxicol 27:338-345

Giamberini L, Beauvais MN, Pihan JC (1996) Implication des hemocytes et du systeme excreteur dans les mecanismes d'accumulation et de detoxication du plomb chez la moule d'eau douce Dreissena polymorpha Pallas: études morphologiques et microanalytiques. Bull Acad Soc Lorraines Sci 35:5-21

Hemelraad J, Herwig HJ, van Donselaar EG, Holwerda DA, Zandee DI (1990) Effects of cadmium in freshwater clams. II. Ultrastructural changes in the renal system of Anodonta cygnea. Arch Environ Contam Toxicol 19:691-698

Holmberg B, Jensen S, Larsson A, Lewander K, Olsson M (1972) Metabolic effects of technical pentachlorophenol (PCP) on the eel Anguilla anguilla L. Comp Biochem Physiol 43:171-183

Hyne V, Smith JD, Ellender G (1992) Tissue and sub-cellular distribution of $\mathrm{Fe}, \mathrm{Cu}, \mathrm{Zn}$ and ${ }^{210} \mathrm{Po}$ in the abalone Haliotis rubra. Mar Biol 112:75-80

Klobučar GIV, Lajtner J, Erben R (1997) Lipid peroxidation and histopathological changes in the digestive gland of a freshwater snail Planorbarius corneus L. (Gastropoda, Pulmonata) exposed to chronic and sub-chronic concentrations of PCP. Bull Environ Contam Toxicol 58:128-134

Krahelska M (1910) Über den Einfluss der Winterruhe auf den histologischen Bau einiger Land-Pulmonaten. Z Naturwiss Jena 46:363-444

Krishnakumar PK, Casillas E, Varanasi U (1994) Effect of environmental contaminants on the health of Mytilus edulis from Puget Sound, Washington, USA. I. Cytochemical measures of lysosomal responses in the digestive cells using automatic image analysis. Mar Ecol Prog Ser 106: 249-261

Lowe DM (1988) Alterations in cellular structure of Mytilus edulis resulting from exposure to environmental contaminants under field and experimental conditions. Mar Ecol Prog Ser 46:91-100

Marigómez JA, Cajaraville MP, Angulo E, Moya J (1990a) Ultrastructural alterations in the renal epithelium of cadmium-treated Littorina littorea (L.). Arch Environ Contam Toxicol 19:863-871

Marigómez JA, Gil JM, Angulo E (1990b) Accumulation of pigment and lipofuscin granules in Littorina littorea exposed to sublethal concentrations of cadmium: a histochemical study. Zool Jb Anat 120:127-141

Marigómez JA, Soto M, Cajaraville MP (1995) Morphofunctional patterns of cell and tissue systems involved in metal handling and metabolism. In: Cajaraville MP (ed) Cell biology in environmental toxicology. University of the Basque Country Press Service, Bilbo, p 89-134

Editorial responsibility: Thomas Braunbeck, Heidelberg, Germany
Pearse AGE (1968) Histochemistry: theoretical and applied. $\mathrm{J} \&$ A Churchill Ltd, London

Potts WTW (1968) Aspects of excretion in the molluscs. In: Fretter V (ed) Studies in the structure, physiology and ecology of molluscs. Academic Press Inc, London, p 187-192

Rand GM, Petrocelli SR (1985) Fundamentals of aquatic toxicology. Hemisphere Publishing Corporation, Washington

Regoli F, Nigro M, Orlando E (1992) Effects of copper and cadmium on the presence of renal concretions in the bivalve Donacilla cornea. Comp Biochem Physiol 102C: 189-192

Rheinberger R, Hoffman G, Yevich P (1979) The kidney of the quahog (Mercenaria mercenaria) as a pollution indicator. In: Animals as monitors of environmental pollutants. Symposium on Pathobiology of Environmental Pollutants. National Academy of Sciences, Washington, DC, p 119-133

Roszell LE, Anderson RS (1996) Effect of chronic in vivo exposure to pentachlorophenol on non-specific immune functions in Fundulus heteroclitus. Mar Environ Res 42: 191-194

Seiler GR, Morse MP (1988) Kidney and hemocytes of Mya arenaria (Bivalvia): normal and pollution-related ultrastructural morphologies. J Invertebr Pathol 52:201-214

Simkiss K, Mason AZ (1983) Metal ions: metabolic and toxic effects. In: Hochachka PW (ed) The Mollusca, Vol 2, Environmental biochemistry and physiology. Academic Press, Inc, New York, p 101-164

Soto M, Marigómez I (1997) Metal bioavailability assessment in 'mussel-watch' programmes by automated image analysis of autometallographic black silver deposits (BSD) in digestive cell lysosomes. Mar Ecol Prog Ser 156:141-150

Sunila I (1986) Histopathological changes in the mussel Mytilus edulis $\mathrm{L}$. at the outlet from a titanium dioxide plant in Northern Baltic. Ann Zool Fenn 23:61-70

Sunila I (1987) Histopathology of mussels (Mytilus edulis L) from the Tvärminne area, the Gulf of Finland (Baltic Sea). Ann Zool Fenn 24: 55-69

Sunila I (1989) Cystic kidneys in copper exposed mussels. Dis Aquat Org 6:63-66

Taylor PM, Andrews EB (1991) Non-protein nitrogen excretion in the prosobranch gastropod Viviparus contectus. J Molluscan Stud 57:391-393

Viarengo A, Nott JA (1993) Mechanisms of heavy metal cation homeostasis in marine invertebrates. Comp Biochem Physiol 104C:355-372

Vivar JL, Mateo A, Angulo E (1990) Histochemistry of the kidney cell granules and concretion in terrestrial snails (Pulmonata: Helicidae, Subulinidae, Elonidae). Gastropodia 2:24-27

Weinbach EC (1954) The effect of pentachlorophenol on oxidative phosphorylation. J Biol Chem 210:545-564

Wendelaar Bonga SE, Boer HH (1969) Ultrastructure of the reno-pericardial system in the pond snail Lymnea stagnalis (L.). Z Zellforsch 94:513-529

WHO (1987) Environmental health criteria 71: Pentachlorophenol. World Health Organization, Geneva

Yevich PP (1980) Comparative histophysiology of excretion in marine molluscs. Thalassia Jugosl 16:2-4

Submitted: September 15, 1999; Accepted: November 18, 2000 Proofs received from author(s): January 29, 2001 